Corrigendum

\title{
Corrigendum to "Protective Effects and Possible Mechanisms of Ergothioneine and Hispidin against Methylglyoxal-Induced Injuries in Rat Pheochromocytoma Cells"
}

\author{
Tuzz-Ying Song $\mathbb{D}^{1},{ }^{1}$ Nae-Cherng Yang $\mathbb{D}^{2,3}$ Chien-Lin Chen $\mathbb{D}^{1},{ }^{1}$ and Thuy Lan Vo Thi ${ }^{1}$ \\ ${ }^{1}$ Department of Bioindustry Technology, Da-Yeh University, Dacun, Taiwan \\ ${ }^{2}$ Department of Nutrition, Chung Shan Medical University Hospital, Taichung, Taiwan \\ ${ }^{3}$ Department of Nutrition, Chung Shan Medical University, Taichung, Taiwan \\ Correspondence should be addressed to Tuzz-Ying Song; song77@mail.dyu.edu.tw \\ Received 19 July 2019; Accepted 26 July 2019; Published 6 August 2019 \\ Copyright ( 2019 Tuzz-Ying Song et al. This is an open access article distributed under the Creative Commons Attribution License, \\ which permits unrestricted use, distribution, and reproduction in any medium, provided the original work is properly cited.
}

In the article titled "Protective Effects and Possible Mechanisms of Ergothioneine and Hispidin against Methylglyoxal-Induced Injuries in Rat Pheochromocytoma Cells" [1], there was a missing affiliation for the second author. The corrected authors' list and affiliations are shown above.

\section{References}

[1] T.-Y. Song, N.-C. Yang, C.-L. Chen, and T. L. V. Thi, "Protective effects and possible mechanisms of ergothioneine and hispidin against methylglyoxal-induced injuries in rat pheochromocytoma cells," Oxidative Medicine and Cellular Longevity, vol. 2017, Article ID 4824371, 10 pages, 2017. 


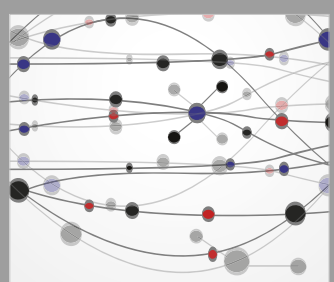

The Scientific World Journal
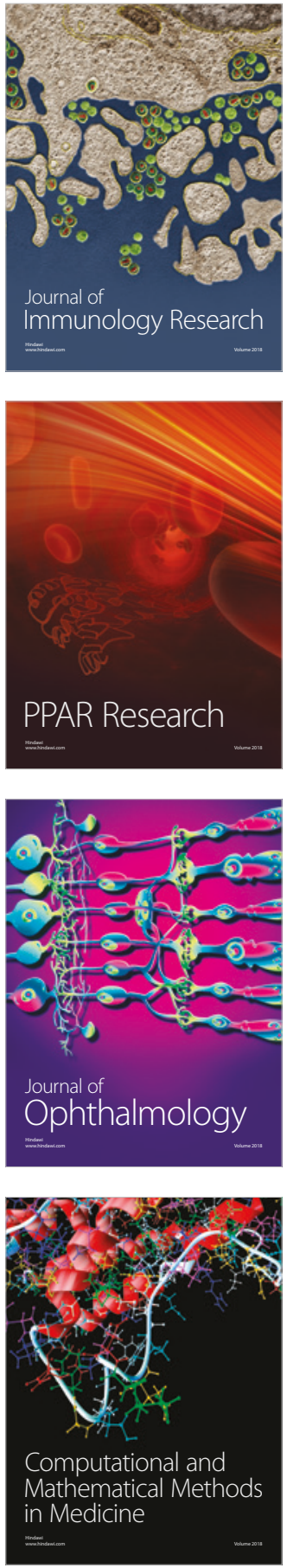

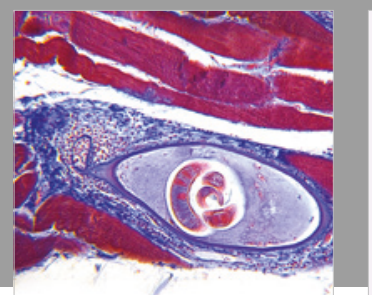

Gastroenterology Research and Practice

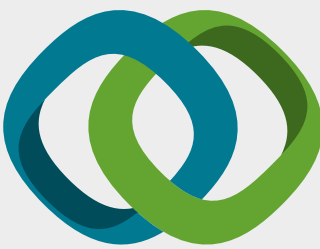

\section{Hindawi}

Submit your manuscripts at

www.hindawi.com
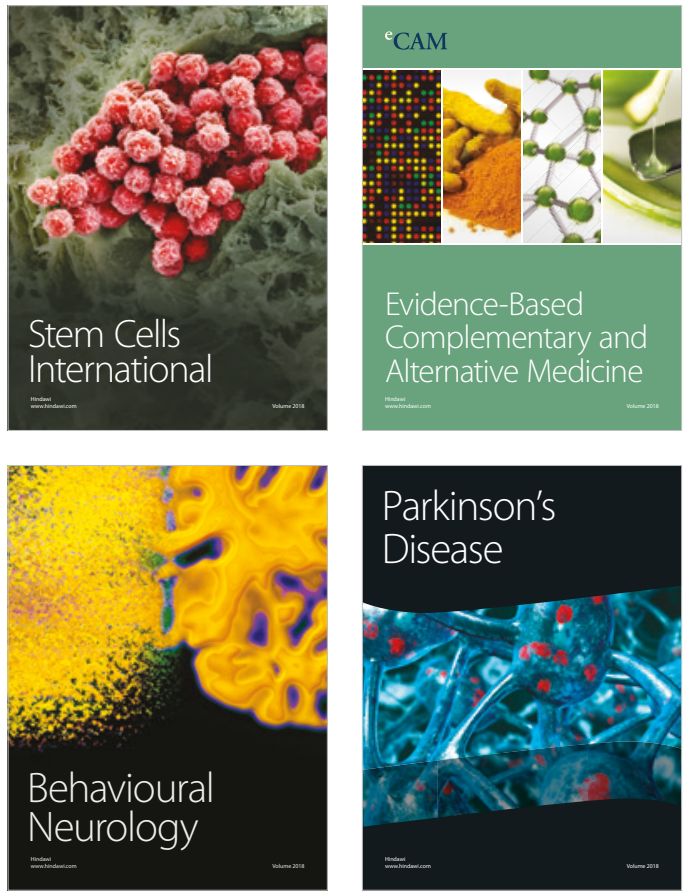

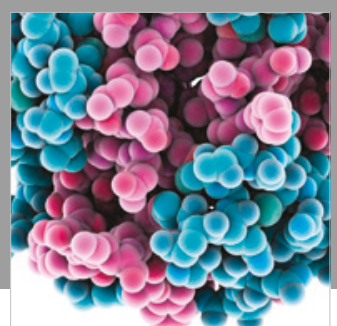

ournal of

Diabetes Research

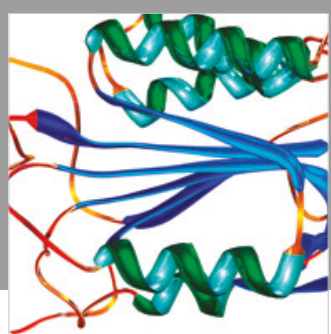

Disease Markers
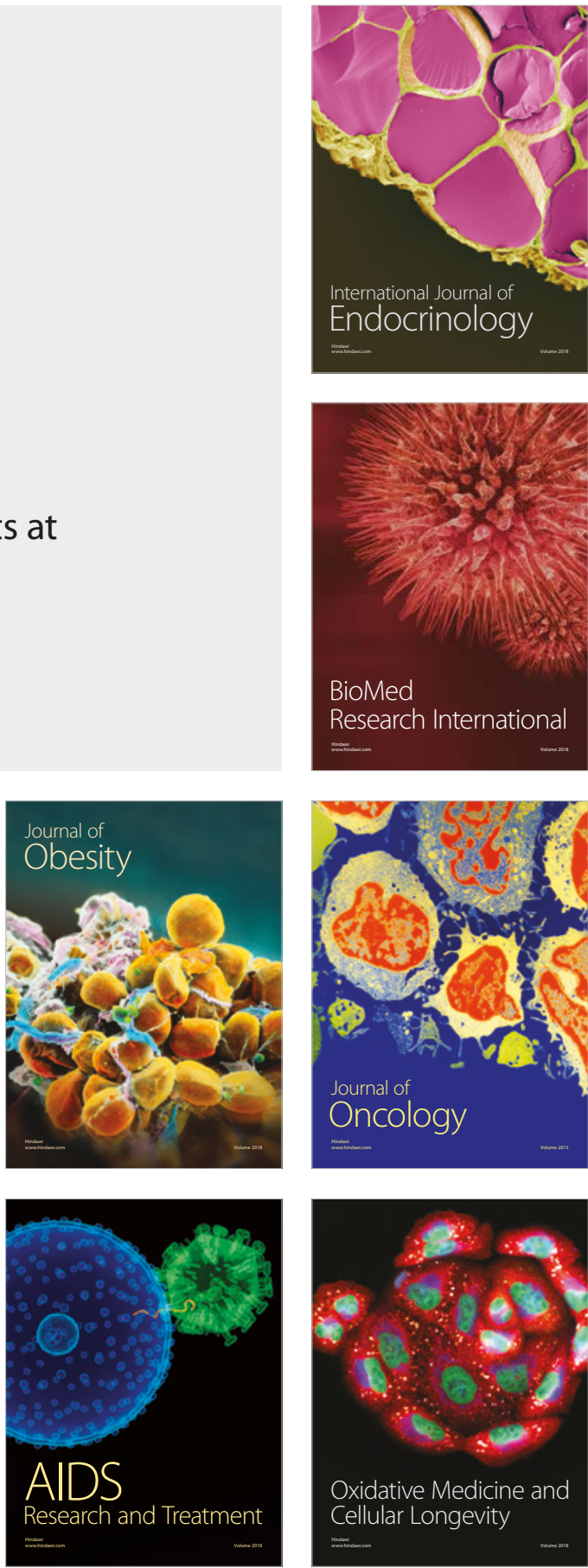